\title{
PENGEMBANGAN MEDIA PEMBELAJARAN DENGAN MENGGUNAKAN ADOBE FLASH CS 6 PADA MATERI HUKUM NEWTON TENTANG GERAK DAN PENERAPANNYA
}

\author{
Meina Oza Setia ${ }^{1}$, Nova Susanti ${ }^{2}$, dan Wawan Kurniawan ${ }^{3}$ \\ 1,2,3 Program Studi Pendidikan Fisika FKIP Universitas Jambi, Jambi, Indonesia \\ Email: meinaozasetia05@yahoo.com
}

\section{Info Artikel}

\section{Alamat Korespondensi: \\ Email:meinaozasetia05@yahoo.com}

\begin{abstract}
Abstrak:
Penelitian ini bertujuan untuk menghasilkan produk akhir dari media pembelajaran fisika dengan menggunakan Adobe flash CS 6 pada pokok bahasan hukum newton tentang gerak dan penerapannya serta mengetahui persepsi siswa. Penelitian ini merupakan penelitian pengembangan (Research and Development). Model pengembangan yang digunakan diadaptasi dari model pengembangan ADDIE (Analysis, Design, Development, Implementation, dan Evaluation). Subjek penelitian ini adalah siswa SMA N 1 Rantau Pandan. Instrumen penelitian yang digunakan adalah lembar observasi, angket validasi ahli media, angket validasi ahli materi dan angket persepsi siswa. Teknik analisis data yang berupa saran dari validator ahli media dan ahli materi dilakukan secara deskriptif kualitatif, sedangkan skor persepsi siswa dilakukan secara statistik deskriptif. Produk yang dihasilkan memiliki spesifikasi antara lain format akhir program adalah swf dan exe, program dilengkapi dengan warna, gambar, teks dan animasi, dan merupakan jenis media audio-visual yang akan dikemas dalam bentuk CD. Keunggulan yang terdapat pada media pembelajaran ini antara lain bahasa yang digunakan mudah dimengerti, gambar ditampilkan jelas, animasi yang menarik, terdapat soal interaktif pada menu evaluasi dan siswa dapat melihat skor yang diperoleh dari tes tersebut. Kelemahan media pembelajaran ini antara lain belum terdapat video dan simulasi pada media pembelajaran, media pembelajaran ini hanya bisa digunakan pada computer atau laptop yang mempunyai aplikasi adobe flash CS 6. Berdasarkan hasil dari persepsi siswa pada indikator tampilan media pembelajaran diperoleh kesimpulan responden menjawab baik pada setiap butir soal dengan rata-rata nilai $78,5 \%$. Berdasarkan hasil dari persepsi siswa pada indikator manfaat penggunaan media pembelajaran diperoleh kesimpulan responden menjawab baik pada setiap butir soal dengan rata-rata nilai $81,73 \%$.
\end{abstract}

Kata Kunci: Media Pembelajaran, Hukum Newton Tentang Gerak Dan Penerapannya, Adobe Flash CS 6 


\section{Pendahuluan}

Fisika merupakan salah satu cabang dari Ilmu Pengetahuan Alam (IPA) yang mempelajari tentang gejala alam dan semua interaksi yang menyertai fenomena tersebut. Pada hakikatnya fisika adalah bagian dari Ilmu Pengetahuan Alam (IPA) yang merupakan proses dan produk tentang pengkajian alam. Menurut pandangan secara umum, masih banyak siswa yang menganggap mata pelajaran fisika sebagai pelajaran paling sulit dan banyak rumusnya sehingga siswa sukar untuk memahami materi yang diajarkan oleh guru.

Bagi siswa bukan hal mudah untuk memahami materi dan persoalan-persoalan yang terdapat dalam fisika. Banyak perhitungan dan pembuktian rumus yang membutuhkan pemahaman mendalam akan konsep-konsep fisika itu sendiri. Kurangnya pemahaman akan suatu konsep membuat siswa sulit menjawab ketika menghadapi soal-soal fisika dengan symbol dan lambang yang berbeda-beda.

Persiapan pembelajaran yang kurang matang dapat menyebabkan kejenuhan siswa dalam mengikuti pelajaran. Seperti halnya ketika media pembelajaran, metode, serta pendekatan pembelajaran yang monoton. Kemonotonan pembelajaran tersebut tentunya, menyebabkan kejenuhan siswa dalam mengikuti pembelajaran. Oleh karena itu, perlu adanya inovasi yang dilakukan oleh guru dalam melakukan suatu pembelajaran. Berdasarkan wawancara yang telah dilakukan dengan guru fisika di SMA N 1 Rantau Pandan pada saat pembelajaran fisika, dari hasil wawancara peneliti mendapat informasi bahwa di SMA N 1 Rantau Pandan dalam penggunaan media masih kurang maksimal, sehingga $90 \%$ siswa merasa cepat bosan dan sulit memahami apa yang disampaikan oleh guru.

Berbagai upaya dapat dilakukan oleh guru untuk meningkatkan kualitas belajar siswa mulai dari melakukan inovasi dalam manajemen kelas, metode pembelajaran, serta media pembelajaran yang relevan. seperti halnya pada saat ini, media pembelajaran merupakan salah satu unsur penting dalam proses belajar mengajar (PBM).

Media apabila dipahami secara garis besar adalah manusia, materi, atau kejadian yang membangun kondisi yang membuat siswa mampu memperoleh pengetahuan, keterampilan atau sikap (Arsyad, 2013). Media pembelajaran dimanfaatkan untuk menunjang tercapainya tujuan tertentu. Pemanfaatannya pun dipadukan dengan proses belajar mengajar dalam situasi kelas. Dalam merencanakan pemanfaatan media itu, guru harus melihat tujuan yang akan dicapai, materi pembelajaran yang mendukung tercapainya tujuan itu, serta strategi belajar mengajar yang sesuai untuk mencapai tujuan itu. Media pembelajaran yang dipilih haruslah sesuai dengan ketiga hal itu, yang meliputi tujuan, materi dan strategi pembelajarannya (Sadiman, 2009). Pemakaian media pembelajaran dalam proses belajar mengajar dapat membangkitkan keinginan dan minat yang baru, membangkitkan motivasi dan rangsangan kegiatan belajar, dan bahkan membawa pengaruh-pengaruh psikologi terhadap siswa (Hamalik, 1986).

Adobe Flash CS 6 merupakan software yang dirancang untuk membuat animasi berbasis vektor dengan hasil yang mempunyai ukuran yang kecil (Madcoms, 2013). Pemilihan teknologi Adobe Flash CS 6 dalam pembuatan media pembelajaran ini karena Adobe Flash CS 6 mendukung penyampaian pesan melalui gambar yang bergerak (animation), teks dan suara. Hal ini akan membantu proses pembelajaran secara audio visual contohnya kasus, pertanyaan, dan lain-lain, sehingga penyajian materi lebih menjadi menarik dibandingkan dengan penjelasan biasa, yang membedakan antara penjelasan guru secara langsung dan media pembelajaran ini adalah pada animasi gambar. Ketika memberi penjelasan, media akan menampilkan gambar animasi yang sesuai dengan materi. Oleh karena itu, siswa dapat menyaksikan aplikasi materi pada bab tersebut dalam kehidupan sehari-hari dengan menyaksikan animasinya. Akan tetapi adanya media ini bukan berarti meniadakan peran guru. Peran guru justru dituntut lebih karena guru harus mampu menjelaskan materi secara menyeluruh baik dari segi teoritis maupun aplikasi. Selain itu, media pembelajaran ini akan memotivasi siswa untuk berpikir kritis dengan memberikan studi kasus. Guru dituntut untuk membantu para siswa dalam menjawab pertanyaan dari siswa itu sendiri jika ada siswa yang mengajukan suatu pertanyaan.

Saputro (2014) dengan mengembangkan Gambar dan Animasi dapat menghasilkan media yang menarik, kemudian 
penelitian dilakukan oleh Perdiansyah (2014) dengan mengembangkan Gambar, Video dan Animasi bergerak. Selanjutnya penelitian yang dilakukan oleh Wakhid (2014), peneliti mengembangkan Gambar, Grafik, Diagram, dan Simulasi. Setelah itu penelitian yang dilakukan oleh Melisa (2014), peneliti mengembangkan Gambar dan Matriks. Dan yang terakhir penelitian yang dilakukan oleh Arifin (2014), peneliti mengembangkan gambar dan animasi. Dari uraian tersebut, maka diperlukan media pembelajaran yang inovatif dalam proses belajar mengajar khususnya dalam materi hukum newton tentang gerak dan penerapannya dengan mengembangkan suatu gambar yang bergerak (animasi), teks, dan suara yang sesuai dengan tujuan pembelajaran sehingga peneliti mengambil judul "Pengembangan media pembelajaran dengan menggunakan adobe flash CS 6 pada materi hukum newton tentang gerak dan penerapannya".

Penelitian ini bertujuan untuk menghasilkan produk akhir dari media pembelajaran fisika dengan menggunakan Adobe flash CS 6 pada pokok bahasan hukum newton tentang gerak dan penerapannya dan untuk mengetahui persepsi siswa mengenai media pembelajaran dengan menggunakan Adobe flash CS 6 pada pokok bahasan hukum newton tentang gerak dan penerapannya. Adapun manfaat dari pengembangan yaitu sebagai media pembelajaran mandiri bagi siswa dan juga dapat mempermudah guru dalam menjelaskan konsep fisika khususnya pada pokok bahasan hukum newton tentang gerak dan penerapannya, dapat menjadi masukan bagi guru dalam meningkatkan kemampuan dan kreatifitas guru untuk merancang dan membuat media pembelajaran berbasis Information and Communication Technology (ICT) serta menambah pengetahuan penulis tentang penggunaan program animasi khususnya dalam pembuatan bahan ajar pembelajaran fisika dengan menggunakan program Adobe Flash CS 6.

\section{Metode Penelitian}

Penelitian ini menggunakan metode penelitian pengembangan atau sering disebut Research and Development. Model pengembangan yang digunakan adalah model penelitian yang diadaptasi dari model pengembangan ADDIE (Analysis, Design, Development, Implementation, dan
Evaluation). Model ini menggunakan 5 tahap yaitu tahap Analysis, Design, Development, Implementation, and Evalution.

1. Analysis (analisis)

Tujuan dari analisis ini adalah untuk mengetahui kebutuhan awal dalam mengembangkan media ini. Diantaranya mengenai analisis kurikulum, analisis karakteristik siswa, analisis pemanfaatan media pembelajaran, serta software Adobe Flash CS 6 yang merupakan software yang akan digunakan dalam mengembangkan media ini.

\section{Design (desain)}

Tahap kedua yaitu tahap pembuatan desain produk yang akan dikembangkan. Peneliti membuat storyboard yang merupakan rancangan secara umum yang meliputi desain template, letak menu, tombol navigasi, dan materi yang akan disajikan.

1) Desain awal media pembelajaran (Pembuka intro media)

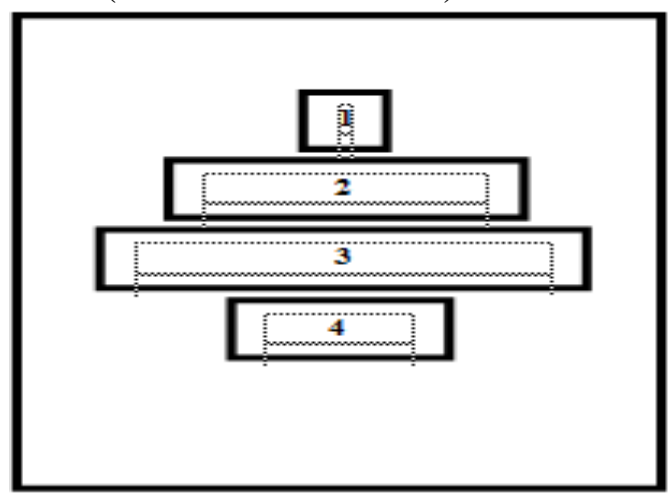

2) Desain awal pembelajaran (Menu utama)

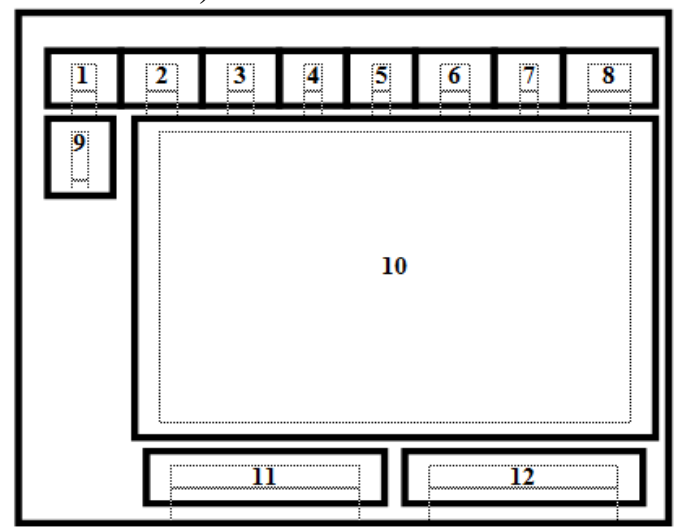


3) Desain awal pembelajaran (Uraian materi)

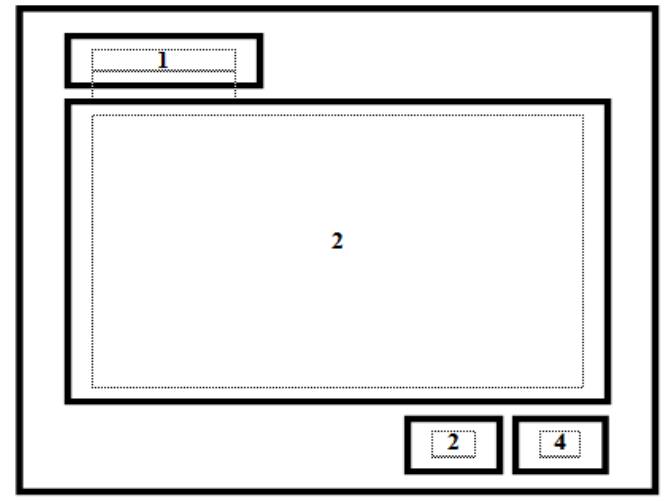

4) Desain awal pembelajaran (Latihan soal)

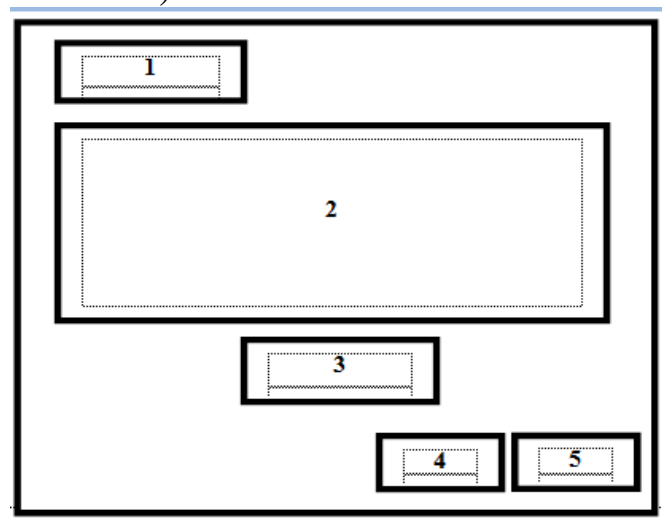

5) Desain awal pembelajaran (Soal evaluasi)

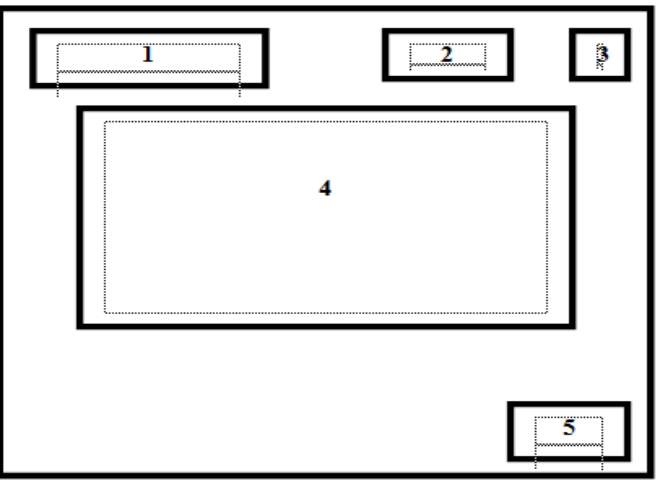

3. Development (Pembuatan Produk)

Pada tahap ini, peneliti melanjutkan pembuatan produk berdasarkan desain yang telah dibuat. Ada tiga bagian utama dalam media ini, yaitu bagian intro, isi, dan penutup. Ketiga bagian tersebut dikembangkan dengan menggunakan aplikasi Adobe Flash CS 6.

4. Implementation (Uji Coba Produk)
Produk yang telah dinyatakan layak uji oleh beberapa Reviewer diujicobakan kepada para siswa. Mereka menggunakan dan mengevaluasi produk tersebut dengan mengisi angket respon untuk siswa. Hal tersebut dimaksudkan untuk mendapatkan masukanmasukan atau koreksi terhadap produk yang telah dikembangkan.

5. Evaluation (Evaluasi)

Dari tahap uji coba akan diperoleh penilaian dan respon dari angket yang diberikan kepada siswa. Angket tersebut akan dianalisis yang selanjutnya dapat diketahui efektivitas media tersebut. Hasil analisis ini digunakan sebagai acuan perlu tidaknya revisi produk tahap akhir.

Subjek Uji Coba

Subjek uji coba penelitian ini adalah siswa SMA N 1 Rantau Pandan yang berjumlah dua puluh delapan siswa.

Instrumen Pengumpulan Data

Adapun instrumen pengumpulan data yang digunakan antara lain..

1. Data kualitatif

Data kualitatif diperoleh dari lembar observasi dan tim validasi yaitu tim ahli materi dan tim ahli media berupa isian angket berupa saran dalam perbaikan media. Sedangkan data kuantitatif diperoleh dari persepsi siswa mengenai media yang dibuat dengan menggunakan program Adobe Flash CS 6. Skala pengukuran yang digunakan untuk pengambilan data adalah skala Guttman. Dimana data yang didapatkan berupa jawaban "ya-tidak".

Data kualitatif tersebut kemudian dianalisis dengan analisis data kualitatif. "Dalam penelitian kualitatif, data diperoleh dari berbagai sumber, dengan menggunakan teknik pengumpulan data yang bermacammacam (triangulasi), dan dilakukan terus menerus sampain datanya jenuh", Sugiyono (2013).

\section{Data Kuantitatif}

Data kuantitatif diperoleh dari angket persepsi siswa mengenai media yang dibuat dengan menggunakan program Adobe Flash CS 6 .

Teknik Analisis Data

1. Analisis data kualitatif 
Teknik analisis data dalam penelitian kualitatif yang berupa saran dari validator ahli materi dan ahli media dilakukan secara deskriptif kualitatif.

a) Observasi

- Reduksi data

Observasi dilakukan dengan cara mengumpulkan data secara langsung dengan menggunakan lembar wawancara. Jenis wawancara yang digunakan adalah wawancara terbuka yang terdiri dari 5 pertanyaan yang sesuai dengan permasalahan penelitian yaitu pengembangan media pembelajaran.

- Penyajian data

Data yang telah direduksi disajikan dalam bentuk kalimat dan dilihat bagaimana jawaban responden mengenai penggunaan media di sekolah tersebut.

- Penarikan kesimpulan

Berdasarkan data yang telah disajikan maka dapat ditarik kesimpulan bahwa dalam penggunaan media masih kurang, oleh karena itu responden memerlukan media pembelajaran yang menarik agar dalam proses pembelajaran siswa tidak merasa bosan, data kualitatif pada tahapan ini disajikan dalam tahap analisis.

b) Saran dari validator ahli media dan ahli materi

- Reduksi data

Saran dari validator ahli media dan ahli materi dicatat terlebih dahulu dalam bentuk teks selanjutnya data yang berbentuk teks direduksi misalnya per indikator pada angket validasi ahli media dan ahli materi.

- Penyajian data

Data yang telah direduksi selanjutnya disajikan dalam bentuk deskripsi, dari deskripsi tersebut maka dapat dilihat bahwa valaidator menyatakan layak atau belum layak media pembelajaran dapat digunakan sebagai sumber belajar bagi siswa.

- Penarikan kesimpulan

Setelah data disajikan maka ditarik kesimpulan bahwa validator menyatakan layak digunakan sebagai salah satu sumber belajar yang bisa digunakan oleh siswa, data kualitatif pada tahapan ini disajikan dalam tahap development.

2. Analisis data kuantitatif
Langkah-langkah menganalisis data angket persepsi siswa adalah sebagai berikut:

a) Mengkuantitatifkan hasil checking dengan memberi skor sesuai dengan bobot yang telah ditentukan sebelumnya.

b) Membuat tabulasi data

c) Menentukan skor rata-rata indikator yang diberikan

$$
\bar{X}=\frac{\sum X}{n}
$$

Keterangan:

$\bar{X} \quad=$ skor rata-rata

$\sum X=$ jumlah skor jawaban responden

$n \quad=$ jumlah responden

d) Mengidentifikasi kecenderungan ubahan setiap sub variabel digunakan rata-rata ideal $(\mathrm{Xi})$ dan standar deviasi ideal (SDi), dapat dihitung dengan acuan norma yaitu:

Xideal $=\frac{1}{2}$ (skor tertingi + skor terendah)

SDideal $=\frac{1}{6}$ (skor tertinggi - skor terendah)

e) Mengkuantitatifkan data menjadi data tabel

Tabel 4. Rentang Skor dan Kriteria Kualitatif

\begin{tabular}{cc}
\hline Rentang Skor & Kriteria \\
\hline$X i+1,5 S D i \leq \bar{X} \leq X i+3,0 S D i$ & Amat \\
$X i+0 S D i \leq \bar{X}<X i+1,5 S D i$ & Baik \\
$X i-1,5 S D i \leq \bar{X}<X i+0 S D i$ & Cukup \\
& Baik \\
$X i-3 S D i \leq \bar{X}<X i-1,5 S D i$ & Kurang \\
Baik \\
\hline (Sumber: Direktorat Pembinaan SMA, 2010)
\end{tabular}

\section{Hasil dan Pembahasan}

1) Hasil Penelitian

1. Analysis (analisis)

a. Analisis Kebutuhan

Berdasarkan hasil observasi dan wawancara pada siswa di kelas X MIPA 1 SMA N 1 Rantau Pandan, didapat bahwa mata pelajaran fisika termasuk mata pelajaran yang 
sulit untuk dipahami. Kesulitan siswa dalam memahami konsep dan tuntutan ketuntasan belajar, membuat siswa lebih cenderung memilih untuk menghafal rumus praktis. Guru hanya menggunakan buku sebagai media pembelajaran sehingga siswa merasa bosan dan kurang tertarik untuk belajar fisika. Dengan demikian siswa butuh media pembelajaran yang menarik agar dapat membantu siswa lebih memahami materi yang diajarkan oleh guru.

Kemudian berdasarkan hasil observasi dan wawancara yang dilakukan terhadap guru fisika di SMA N 1 Rantau Pandan, diperoleh informasi bahwa guru membutuhkan media pembelajaran yang menarik yang dapat membantu siswa dalam memahami materi dan juga siswa tidak merasa bosan ketika proses pembelajaran berlangsung dengan media pembelajaran yang menyajikan suatu gambar, audio, dan animasi bergerak. Untuk itu berdasarkan kajian penulis, media yang sesuai adalah media pembelajaran yang menggunakan aplikasi Adobe Flash CS 6.

b. Analisis awal-akhir

Dalam tahap ini ada beberapa hal yang dianalisis oleh penulis, antara lain yaitu karakteristik siswa. Berdasarkan hasil observasi yang dilakukan terhadap siswa kelas X MIPA 1 SMA N 1 Rantau Pandan, diperoleh data bahwa siswa berusia antara 16-18 tahun dan telah dikenalkan dengan TIK sejak menduduki bangku Sekolah Dasar (SD).

Salah satu upaya yang dilakukan oleh guru yaitu dengan mengidentifikasi perilaku dan karakteristik awal siswa guna memperoleh informasi yang lengkap dan akurat berkenaan dengan kemampuan serta karakteristik awal siswa sebelum proses pembelajaran berlangsung selanjutnya menyeleksi tuntutan, bakat, minat, kemampuan, serta kecenderungan siswa. Tahapan ini biasanya dilakukan saat penyeleksian siswa baru, hal ini penting dilakukan dan dikembangkan sesuai dengan kemampuan siswa.

Kemudian penulis menganalisis sarana pendukung yang ada di SMA N 1 Rantau Pandan. Berdasarkan analisis tehnologi yang penulis lakukan, maka didapatlah data bahwa di SMA N 1 Rantau Pandan sarana yang dibutuhkan dan diperlukan saat proses pembelajaran masih kurang maksimal, dengan kata lain banyak komputer yang rusak atau tidak layak pakai hanya beberapa yang layak digunakan, namun pada penelitian kali ini penulis tidak menggunakan komputer melainkan laptop. Perangkat pendukung pembelajaran untuk menayangkan media pembelajaran Hukum Newton Tentang Gerak dan Penerapannya dengan menggunakan media pembelajaran berbasis Adobe Flash CS 6 ini, antara lain: listrik, laptop, proyektor (LCD) Liquid Crystal Display, layar monitor, dan speaker.

Kemudian langkah selanjutnya yang dilakukan penulis yaitu menganalisis media pembelajaran, dimana setiap standar kompetensi yang tampilkan didalam media pembelajaran senantiasa terkait dengan kompetensi dasar dan indikatornya, dan untuk memudahkan siswa memahami materi yang dipelajari, didalam media pembelajaran tersebut selain ditampilkan dalam bentuk teks juga disertai dengan contoh dalam bentuk gambar dan juga animasi yang bergerak.

2. Design (desain)

Tahap desain pada pengembangan media pembelajaran ini meliputi beberapa tahapan, yaitu :

1) Jadwal : Pengembangan produk media pembelajaran Hukum Newton Tentang Gerak dan Penerapannya dengan menggunakan Adobe Flash CS 6, ini menghabiskan waktu sekitar lima bulan yaitu dari bulan Oktober - Maret 2017, berikut jadwal pembuatan produk

2) Team : Dalam pembuatan media pembelajaran Adobe Flash CS 6 ini tentunya memerlukan team kerja yang memiliki peran dan tugas masing-masing demi terciptanya sebuah produk yang baik dan bermanfaat bagi dunia pendidikan pada umumnya dan khususnya bagi siswa disekolah tersebut. Adapun team yang terlibat dalam pengembangan media pembelajaran ini terdiri dari: peneliti sebagai sebagai penulis produk, tim ahli yang akan menilai produk sekaligus merevisi. Tim Ahli ini terdiri dari empat orang yaitu dua ahli media dan dua ahli materi, serta siswa khususnya kelas $\mathrm{X}$ MIPA 1 SMA N 1 Rantau Pandan sebagai pemakai sekaligus penilai produk pada tahap uji coba lapangan.

3) Spesifikasi media : Produk media pembelajaran tentang Hukum Newton 
Tentang Gerak dan Penerapannya dibuat dengan menggunakan program aplikasi Adobe Flash CS 6. Adapun spesifikasi produk yang dihasilkan memuat tomboltombol, teks, narasi, dan audio serta aplikasi lain yang dibutuhkan demi kualitas produk. Spesifikasi media pembelajaran ini dapat dijelaskan sebagai berikut:

a) Media pembelajaran ini memuat materi pembelajaran fisika dengan materi Hukum Newton Tentang Gerak dan Penerapannya dengan menampilkan suatu gambar, teks, animasi, dan audio yang menggunakan aplikasi Adobe Flash CS 6.

b) Program yang dipakai adalah Adobe Flash CS 6.

c) Materi-materi dipisahkan dalam scene yang berbeda.

d) Tampilan beranda dirancang sedemikian rupa guna mempermudah saat proses pembelajaran yang tentunya menarik dan sesuai dengan materi yang sedang dipelajari.

e) Jenis huruf yang dipakai adalah Times New Roman dengan ukuran 12.

f) Standar interaksi dan umpan balik berupa soal interaktif.

\section{4) Struktur materi}

Dalam tahap ini materi pembelajaran dan struktur materi yang dikembangkan dalam bentuk media pembelajaran dijabarkan sebagai berikut : 1) Mengidentifikasi standar kompetensi pembelajaran; 2) Menganalisis 3) kompetensi dasar pembelajaran; Menetapkan tujuan pembelajaran; 4) Merumuskan indikator keberhasilan; 5) Menyusun strategi pembelajaran; 6) Mengembangkan materi pembelajaran; 7) Merancang sistem penilaian dan evaluasi.

5) Kontrol konvigurasi dan evaluasi

Langkah ini merupakan langkah terakhir yang dibutuhkan dalam merancang serangkaian spesifikasi desain media pembelajaran dengan menggunakan Adobe Flash CS 6, sebelum produk ini di validasi oleh para ahli untuk di review. Pada tahap ini tugas penulis adalah mencatat hal yang perlu diperbaiki dan menyiapkan lembar penilaian.

6) Pengulangan dan evaluasi
Pengulangan dan evaluasi dilakukan setelah produk akan digunakan dilapangan. Evaluasi berupa evaluasi materi, media, desain maupun isi produk. Evaluasi dilakukan oleh seorang ahli dibidangnya. Hal ini bertujuan untuk menemukan kekurangan-kekurangan yang terdapat pada media pembelajaran yang telah dibuat sehingga dapat menghasilkan sebuah produk berupa media pembelajaran yang berkualitas dan diterima oleh siswa maupun guru bidang studi fisika.

\section{Development (Pembuatan Produk)}

Dalam tahap mengembangkan produk, prosedur yang dilakukan oleh penulis adalah pembuatan produk awal dengan terlebih dahulu mempersiapkan bahan, penetapan kompetensi dasar, tujuan pembelajaran, materi pembelajaran dan evaluasi. Tahap ini adalah tahap pembuatan produk yang berupa media pembelajaran Hukum Newton Tentang Gerak dan Penerapannya dengan menggunakan Adobe Flash CS 6.

Selanjutnya adalah kegiatan produksi media, dalam hal ini penulis dibantu oleh programer yang memang mengerti dan memahami cara pembuatan media pembelajaran dengan menggunakan Adobe Flash CS 6.

\section{Implementation (Uji Coba Produk)}

Tahap ini merupakan tahap dimana penulis melakukan penerapan dan uji coba produk yang telah dibuat dengan menggunakan Adobe Flash CS 6 pada materi Hukum Newton Tentang Gerak dan Penerapannya yang diterapkan kepada siswa kelas X MIPA 1 SMA N 1 Rantau Pandan. Uji coba media pembelajaran ini yaitu uji coba lapangan. Uji coba produk dilakukan untuk melihat kelayakan media dan persepsi siswa mengenai media pembelajaran tersebut melalui pengisisan angket persepsi siswa, angket yang digunakan pada saat uji coba lapangan adalah angket yang sudah valid. Keseluruhan kegiatan uji coba ini dilaksanakan pada siswa kelas $\mathrm{X}$ MIPA 1 SMA N 1 Rantau Pandan yang berjumlah 28 siswa.

\section{Evaluation (Evaluasi)}

Tahap ini merupakan tahap akhir dari pengembangan produk yang telah dihasilkan dengan menggunakan Adobe Flash CS 6 . Evaluasi ini dilakukan oleh pengguna (siswa 
dan guru) dengan tujuan untuk mengukur respon pengguna pada aktivitas yang telah dilakukannya.

\section{2) Penyajian Hasil validasi}

Validasi merupakan evaluasi terhadap produk awal yang telah dikembangkan dengan tujuan untuk melihat aspek kebenaran isi media dan tampilan media dengan melibatkan ahli media dan ahli materi. Media pembelajaran yang telah dihasilkan kemudian divalidasi oleh validator yang terdiri dari empat orang yaitu dua ahli materi dan dua ahli media.

\section{Validasi ahli materi}

Hasil validasi tahap pertama oleh ahli materi yaitu ibu Nova Susanti, S.Pd.,M.Si sebagai validator materi.

Hasil validasi materi tahap I ini validator materi menyarankan :

1. Tambahkan materi tentang gaya.

2. Sesuaikan materi dengan konsep pembelajaran.

3. Masukkan indikator pembelajaran.

4. Ada beberapa tombol navigasi yang belum bisa digunakan sebaiknya dilengkapi agar berfungsi dengan baik

5. Masukkan soal latihan dan penyelesaian.

6. Buat kisi-kisi soal untuk mengetahui tingkat kompleksitas soal.

7. Perbaiki bahasa yang digunakan agar mudah dipahami oleh siswa.

Hasil validasi tahap kedua oleh ahli materi. Hasil validasi materi tahap II ini validator materi menyarankan :

1. Sesuaikan gambar dengan tulisan, perbaiki gambar yang masih belum jelas.

2. Latihan soal ditambahkan.

3. Tambahkan soal di evaluasi.

Hasil validasi tahap ketiga oleh ahli materi. Hasil validasi materi tahap III ini validator materi menyarankan :

1. Sesuaikan materi dengan konsep materi yang akan disajikan kedalam media pembelajaran.

2. Lengkapi materi yang belum lengkap.

3. Tambahkan latihan soal.

4. Perbaiki kisi-kisi soal untuk mengetahui tingkat kesulitan soal.

Hasil validasi tahap keempat oleh ahli materi dapat dilihat pada tabel 5 .
Tabel 5. Hasil validasi tahap keempat dari angket ahli materi

\begin{tabular}{|c|c|c|c|c|}
\hline No & Pertanyaan & Ya & Tidak & Komentar \\
\hline 1. & $\begin{array}{l}\text { Apakah program sesuai dengan } \\
\text { Standar Kompetensi }\end{array}$ & & & \\
\hline 2. & $\begin{array}{l}\text { Apakah indikator sesuai dengan } \\
\text { kompetisi dasar? }\end{array}$ & & & \\
\hline 3. & $\begin{array}{l}\text { Apakah program memberikan } \\
\text { petunjuk penggunaan media? }\end{array}$ & $\checkmark$ & & \\
\hline 4. & $\begin{array}{l}\text { Apakah program menyajikan } \\
\text { materi ? }\end{array}$ & V & & \\
\hline 5. & $\begin{array}{l}\text { Apakah isi materi mempunyai } \\
\text { konsep yang benar? }\end{array}$ & $\checkmark$ & & \\
\hline 6. & $\begin{array}{l}\text { Apakah program mudah untuk } \\
\text { dipakai dalam pembelajaran ? }\end{array}$ & & & \\
\hline 7. & $\begin{array}{l}\text { Apakah program memberikan } \\
\text { latihan untuk pemahaman konsep? }\end{array}$ & U & & \\
\hline 8. & $\begin{array}{l}\text { Apakah program memiliki soal } \\
\text { yang variatif }\end{array}$ & & & \\
\hline 9. & $\begin{array}{l}\text { Apakah program dapat mengukur } \\
\text { kemampuan siswa? }\end{array}$ & $\checkmark$ & & \\
\hline 10. & Apakah terdapat fasilitas latiham & U & & - \\
\hline & dan penyelesaian? & $\checkmark$ & & \\
\hline 11. & $\begin{array}{l}\text { Apakah bahasa yang digunakan } \\
\text { mudah dan tepat? }\end{array}$ & $\checkmark$ & & \\
\hline 12. & $\begin{array}{l}\text { Apakah bahasa yang digunakan } \\
\text { mudah dimengerti? }\end{array}$ & $\checkmark$ & & \\
\hline 13. & $\begin{array}{l}\text { Apakah pengorganisasian soal } \\
\text { sudah sistematis sesuai tingkat } \\
\text { kesulitan? }\end{array}$ & $\checkmark$ & & \\
\hline
\end{tabular}

Hasil validasi materi tahap IV ini validator materi yaitu ibu Nova Susanti, S.Pd.,M.Si, validator telah memberi jawaban Ya untuk semua pertanyaan validasi dan menyatakan media fisika ini sudah layak untuk digunakan.

Selanjutnya hasil validasi tahap pertama oleh ahli materi yaitu bapak Ahmad Syarkowi, M.Pd sebagai validator materi.

Hasil validasi materi tahap I ini validator materi menyarankan :

1. Icon media pada materi diganti, sesuai dengan materinya.

2. Timing aplikasi dipercepat.

3. Indikator harus dari $\mathrm{C} 1-\mathrm{C} 4$.

4. Untuk memudahkan perumusan tujuan yang diharapkan sebaiknya berpedoman pada rumus ABCD yaitu audiance, behaviour, conditioning, degree.

5. Symbol $₫$ diganti jadi $w$.

6. Sesuaikan gambar dengan symbol.

Hasil validasi tahap kedua oleh ahli materi dapat dilihat pada tabel 6 .

Tabel 6. Hasil validasi tahap kedua dari angket ahli materi 


\begin{tabular}{|c|c|c|c|c|}
\hline No & Pertanyaan & Ya & Tidak & Komentar \\
\hline 1. & $\begin{array}{l}\text { Apakah program sesuai dengan } \\
\text { Standar Kompetensi }\end{array}$ & $\checkmark$ & & \\
\hline 2. & $\begin{array}{l}\text { Apakah indikator sesuai dengan } \\
\text { kompetisi dasar? }\end{array}$ & & & \\
\hline 3. & $\begin{array}{l}\text { Apakah program memberikan } \\
\text { petunjuk penggunaan media? }\end{array}$ & & & \\
\hline 4. & $\begin{array}{l}\text { Apakah program menyajikan } \\
\text { materi ? }\end{array}$ & $\checkmark$. & & \\
\hline 5. & $\begin{array}{l}\text { Apakah isi materi mempunyai } \\
\text { konsep yang benar? }\end{array}$ & & & \\
\hline 6. & $\begin{array}{l}\text { Apakah program mudah untuk } \\
\text { dipakai dalam pembelajaran ? }\end{array}$ & & & \\
\hline 7. & $\begin{array}{l}\text { Apakah program memberikan } \\
\text { latihan untuk pemahaman konsep? }\end{array}$ & $u$ & & \\
\hline 8. & $\begin{array}{l}\text { Apakah program memiliki soal } \\
\text { yang variatif }\end{array}$ & & & \\
\hline 9. & $\begin{array}{l}\text { Apakah program dapat mengukur } \\
\text { kemampuan siswa? }\end{array}$ & & & \\
\hline 10. & Apakah terdapat fasilitas latiham & & & 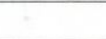 \\
\hline & dan penyelesaian? & & & \\
\hline 11. & $\begin{array}{l}\text { Apakah bahasa yang digunakan } \\
\text { mudah dan tepat? }\end{array}$ & & & . \\
\hline 12. & $\begin{array}{l}\text { Apakah bahasa yang digunakan } \\
\text { mudah dimengerti? }\end{array}$ & & & \\
\hline 13. & $\begin{array}{l}\text { Apakah pengorganisasian soal } \\
\text { sudah sistematis sesuai tingkat } \\
\text { kompleksitas? }\end{array}$ & V & & \\
\hline
\end{tabular}

Hasil validasi materi tahap II ini validator materi yaitu bapak Ahmad Syarkowi, M.Pd, validator telah memberi jawaban Ya untuk semua pertanyaan validasi dan menyatakan media fisika ini sudah layak untuk digunakan.

2. Validasi ahli media

Media pembelajaran dengan menggunakan Adobe Flash CS 6 pada materi Hukum Newton tentang Gerak dan Penerapannya untuk siswa kelas X SMA yang telah selesai divalidasi oleh ahli materi kemudian dilanjutkan validasi oleh ahli media pembelajaran yaitu Bapak Wawan Kurniawan, S.Si.,M.Cs dan Dwi Kurniawan, S.Kom.

Hasil validasi media tahap I ini validator media menyarankan :

1. Letakkan posisi button sesuai porsinya

2. Perbesar huruf di slide

3. Tampilan di media diperlebar, agar pengguna bisa melihat dengan jelas.

4. Sesuaikan letak gambar dengan materi, agar mudah dipahami oleh pengguna media.

Hasil validasi tahap kedua oleh ahli media. Hasil validasi media tahap II ini validator media menyarankan :

1. Tombol navigasi diperbaiki agar mudah di operasikan.

2. Latihan soal diperbaiki, masih ada huruf yang tidak terbaca.
Hasil validasi tahap ketiga oleh ahli media dapat dilihat pada tabel 7 .

Tabel 7. Hasil validasi ketiga oleh ahli media

\begin{tabular}{|c|c|c|c|c|}
\hline No & Pertanyaan & Ya & Tidak & Komentar \\
\hline 1. & $\begin{array}{l}\text { Apakah program menggunakan } \\
\text { navigasi yang mudah? }\end{array}$ & & & \\
\hline 2. & $\begin{array}{l}\text { Apakah navigasi tepat dengan } \\
\text { menu yang diinginkan? }\end{array}$ & & & \\
\hline 3. & $\begin{array}{l}\text { Apakah pengoperasian program } \\
\text { mudah ? }\end{array}$ & $\checkmark$ & & \\
\hline 4. & $\begin{array}{l}\text { Apakah program dapat berjalan } \\
\text { dengan baik? }\end{array}$ & & & \\
\hline 5. & $\begin{array}{l}\text { Apakah program bebas dari } \\
\text { kesalahan yang mengakibatkan } \\
\text { berhentinya program? }\end{array}$ & & & \\
\hline 6. & $\begin{array}{l}\text { Apakah ada keterkaitan gambar } \\
\text { dengan materi ? }\end{array}$ & & & \\
\hline 7. & $\begin{array}{l}\text { Apakah program menggunakan } \\
\text { musik yang sesuai ? }\end{array}$ & & & \\
\hline 8. & $\begin{array}{l}\text { Apakah program menggunakan } \\
\text { animasi yang menarik ? }\end{array}$ & & & \\
\hline 9. & $\begin{array}{l}\text { Apakah program menggunakan } \\
\text { bahasa yang mudah dimengerti? }\end{array}$ & & & \\
\hline 10. & Apakah media menarik ? & $\checkmark$ & & \\
\hline 11. & $\begin{array}{l}\text { Apakah media menyenangkan } \\
\text { saat dimainkan? }\end{array}$ & U & & \\
\hline 12. & $\begin{array}{lrr}\text { Apakah } & \text { pengguna } & \text { dapat } \\
\text { menilai } & \text { kemampuan } & \text { sendiri } \\
\text { setelah } & \text { menggunakan } & \text { program } \\
?\end{array}$ & $V$ & & \\
\hline 13. & $\begin{array}{l}\text { Apakah tulisan teks dapat } \\
\text { dibaca dengan jelas? }\end{array}$ & $v$ & & \\
\hline 14. & Apakah ukuran huruf sesuai ? & $\checkmark$ & & \\
\hline 15. & Apakah warna hufur sesuai ? & 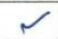 & & \\
\hline 16. & $\begin{array}{l}\text { Apakah terdapat fasilitas latihan } \\
\text { dan penyelesaian? }\end{array}$ & 乙 & & \\
\hline 17. & $\begin{array}{l}\text { Apakah tata letak gambar } \\
\text { sesuai ? }\end{array}$ & 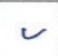 & & \\
\hline 18. & $\begin{array}{l}\text { Apakah peletakan konten tepat } \\
\text { ? }\end{array}$ & $v$ & & \\
\hline 19. & 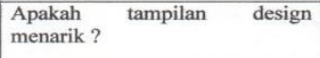 & $\checkmark$ & & \\
\hline 20. & $\begin{array}{l}\text { Apakah warna tulisan dan } \\
\text { bacground sesuai ? }\end{array}$ & L & & \\
\hline
\end{tabular}

Setelah media selesai direvisi oleh validator media bapak Wawan Kurniawan, S.Si.,M.Cs sesuai dengan saran yang diberikan validator, maka dilakukan validasi tahap ke tiga. Untuk validasi tahap ketiga ini validator menyatakan media sudah layak untuk digunakan sebagai bahan ajar.

Kemudian hasil validasi tahap pertama oleh ahli media yaitu bapak Dwi Kurniawan, S.Kom sebagai validator media.

Hasil validasi media tahap I ini validator media menyarankan :

1. Tambahkan menu interaktif kedalam media.

2. Tambahkan button next dan back di kompetensi dasar.

Hasil validasi tahap kedua oleh ahli media dapat dilihat pada tabel 8 . 
Tabel 8. Hasil validasi ketiga oleh ahli media

\begin{tabular}{|c|c|c|c|c|}
\hline No & Pertanyaan & Ya & Tidak & Komentar \\
\hline 1. & $\begin{array}{l}\text { Apakah program menggunakan } \\
\text { navigasi yang mudah? }\end{array}$ & V & & \\
\hline 2. & $\begin{array}{l}\text { Apakah navigasi tepat dengan } \\
\text { menu yang diinginkan? }\end{array}$ & V & & \\
\hline 3. & $\begin{array}{l}\text { Apakah pengoperasian program } \\
\text { mudah? }\end{array}$ & V & & \\
\hline 4. & $\begin{array}{l}\text { Apakah program dapat berjalan } \\
\text { dengan baik? }\end{array}$ & $V$ & & \\
\hline 5. & $\begin{array}{l}\text { Apakah program bebas dari } \\
\text { kesalahan yang mengakibatkan } \\
\text { berhentinya program? }\end{array}$ & $V$ & & \\
\hline 6. & $\begin{array}{l}\text { Apakah ada keterkaitan gambar } \\
\text { dengan materi? }\end{array}$ & U & & \\
\hline 7. & $\begin{array}{l}\text { Apakah program menggunakan } \\
\text { musik yang sesuai? }\end{array}$ & 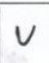 & & \\
\hline 8. & $\begin{array}{l}\text { Apakah program menggunakan } \\
\text { animasi yang menarik? }\end{array}$ & $N$ & & \\
\hline 9. & $\begin{array}{l}\text { Apakah program menggunakan } \\
\text { bahasa yang mudah dimengerti? }\end{array}$ & $V$ & & \\
\hline 10. & Apakah media menarik ? & $\checkmark$ & 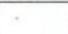 & \\
\hline 11. & $\begin{array}{l}\text { Apakah media menyenangkan } \\
\text { saat dimainkan? }\end{array}$ & $U$ & & \\
\hline 12. & $\begin{array}{l}\text { Apakah pengguna dapat menilai } \\
\text { kemampuan sendiri setelah } \\
\text { menggunakan program? }\end{array}$ & $V$ & & \\
\hline 13. & $\begin{array}{l}\text { Apakah tulisan teks dapat dibaca } \\
\text { dengan jelas? }\end{array}$ & $V$ & & \\
\hline 14. & Apakah ukuran huruf sesuai ? & $\checkmark$ & & \\
\hline 15. & Apakah warna hufur sesuai ? & $V$ & & \\
\hline 16. & $\begin{array}{l}\text { Apakah terdapat fasilitas latihan } \\
\text { dan penyelesaian? }\end{array}$ & $V$ & & \\
\hline 17. & $\begin{array}{l}\text { Apakah tata letak gambar } \\
\text { sesuai? }\end{array}$ & $\checkmark$ & & \\
\hline 18. & Apakah peletakan konten tepat? & $\checkmark$ & & \\
\hline 19. & $\begin{array}{lll}\text { Apakah tampilan } & \text { design } \\
\text { menarik? } & & \\
\end{array}$ & $\checkmark$ & & \\
\hline 20. & $\begin{array}{l}\text { Apakah warna tulisan dan } \\
\text { bacground sesuai ? }\end{array}$ & $\checkmark$ & & \\
\hline
\end{tabular}

Hasil validasi media tahap II ini validator media yaitu bapak Dwi Kurniawan, S.Kom validator telah memberi jawaban Ya untuk semua pertanyaan validasi dan menyatakan media fisika ini sudah layak untuk digunakan.

Dengan demikian setelah divalidasi oleh validator yaitu ahli materi dan ahli media, pada validasi tahap terakhir ini validator menyatakan bahwa media pembelajaran dengan menggunakan Adobe Flash CS 6 sudah layak digunakan.

Setelah melakukan pemeriksaan dari para ahli media, selanjutnya peneliti mengadakan uji coba lapangan untuk melihat respon berupa persepsi dari siswa SMA Kelas $\mathrm{X}$ MIPA 1 dengan menyebarkan angket. Penelitian ini dilaksanakan pada tanggal 7 Agustus 2017. Peneliti mengambil tempat uji coba di SMA N 1 Rantau Pandan dengan jumlah sempel 28 orang.

Hasil penyebaran angket berupa data tentang persepsi siswa terhadap media pembelajaran dengan menggunakan adobe flash CS 6 adalah sebagai berikut:

Tabel 9. Hasil Penyebaran angket persepsi kepada siswa kelas X MIPA 1

\begin{tabular}{ccc}
\hline Indikator & Skor & Kriteria \\
\hline $\mathbf{1}$ & 4,28 & Amat baik \\
$\mathbf{2}$ & 3,75 & Baik \\
$\mathbf{3}$ & 3,82 & Baik \\
$\mathbf{4}$ & 3,89 & Baik \\
$\mathbf{5}$ & 4 & Baik \\
$\mathbf{6}$ & 3,82 & Baik \\
$\mathbf{7}$ & 4,17 & Baik \\
$\mathbf{8}$ & 3,85 & Baik \\
$\mathbf{9}$ & 3,96 & Baik \\
$\mathbf{1 0}$ & 4,35 & Baik \\
\hline
\end{tabular}

Kajian Produk Akhir

Produk yang dihasilkan dalam pengembangan ini adalah media pembelajaran berbantuan komputer untuk siswa SMA kelas $\mathrm{X}$ yang disajikan dalam bentuk $\mathrm{CD}$ pembelajaran.

Media pembelajaran yang dikembangkan memilki komponen-komponen antara lain:

1. Media pembelajaran diformat dalam program swf dan exe.

2. Sub materi yang dibahas berdasarkan pada silabus kurikulum 2013 yaitu hukum newton tentang gerak dan pnerapannya.

3. Media pembelajaran ini dapat digunakan pada tingkat sekolah menengah atas kelas X SMA.

4. Media pembelajaran ini merupakan jenis media audio-visual yang akan dikemas dalam bentuk CD.

Adapun kajian produk akhir dari media pembelajaran yang telah dikembangkan sebagai berikut:

1. Tampilan pembuka 


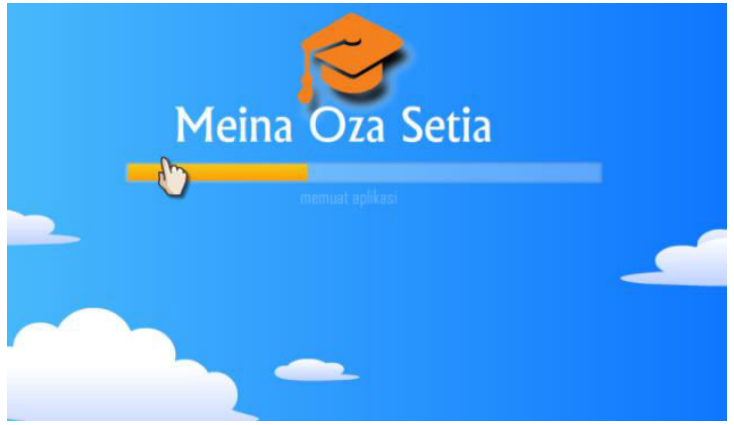

5. Tampilan materi pengantar

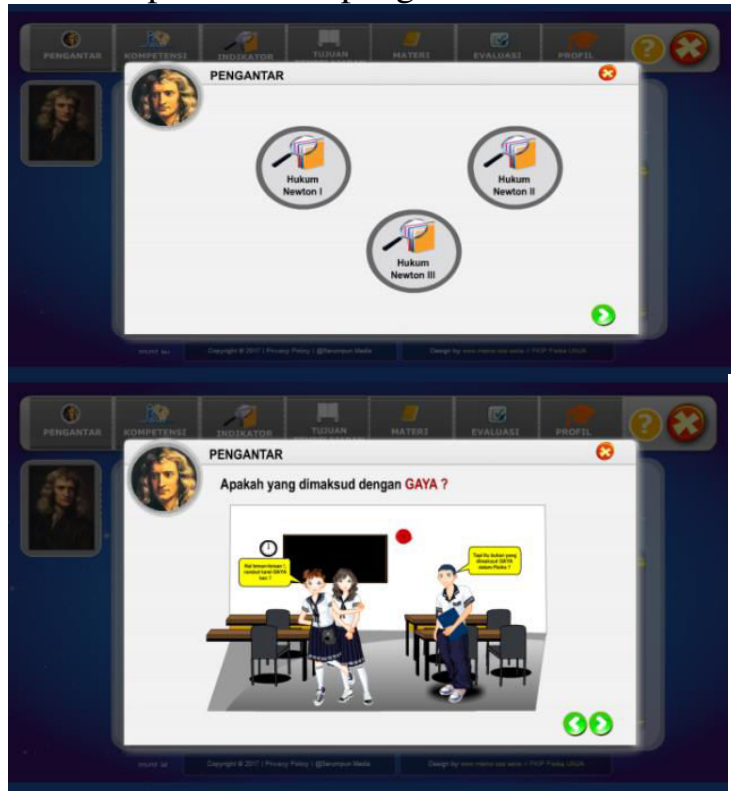

\section{Tampilan menu}

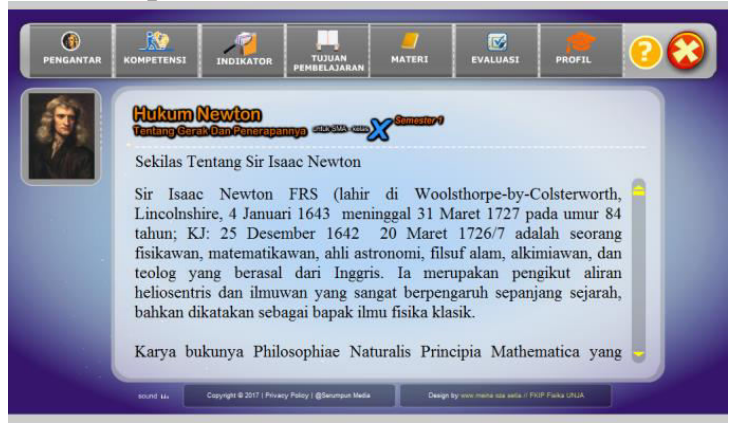

3. Tampilan kompetensi

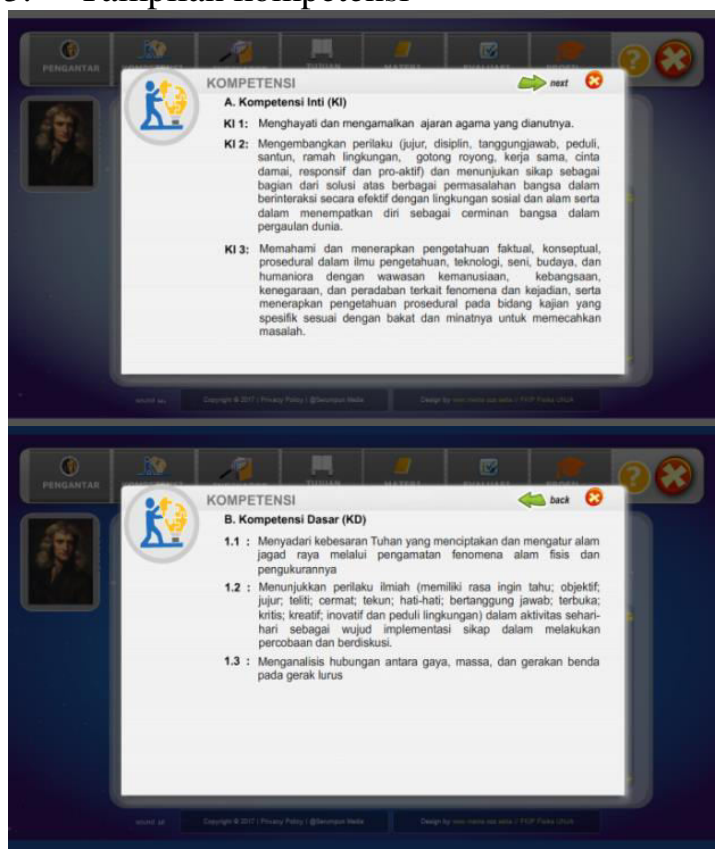

4. Tampilan tujuan pembelajaran

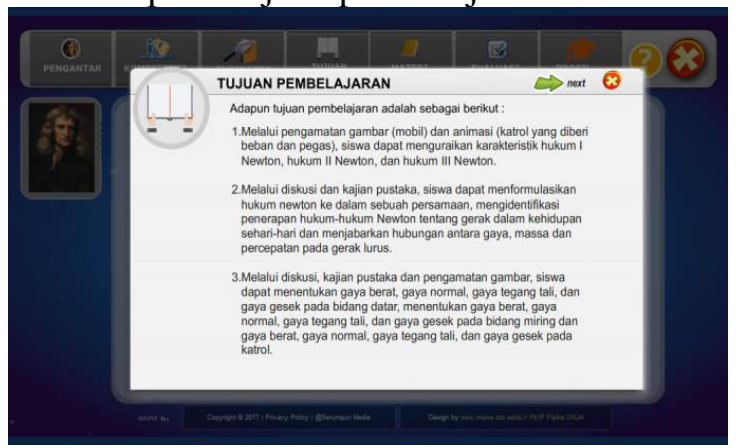

6. Tampilan menu materi

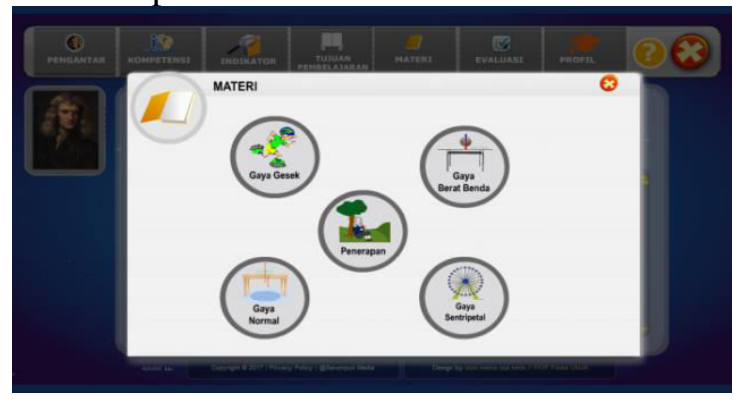

7. Tampilan latihan soal dan penyelesaian

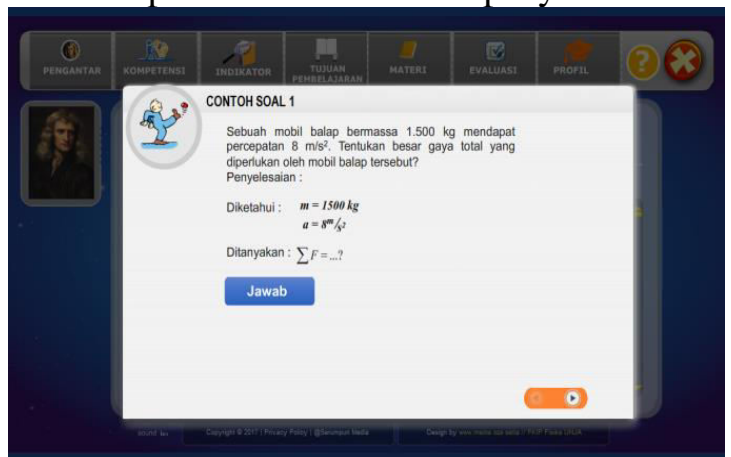

8. Tampilan soal evaluasi

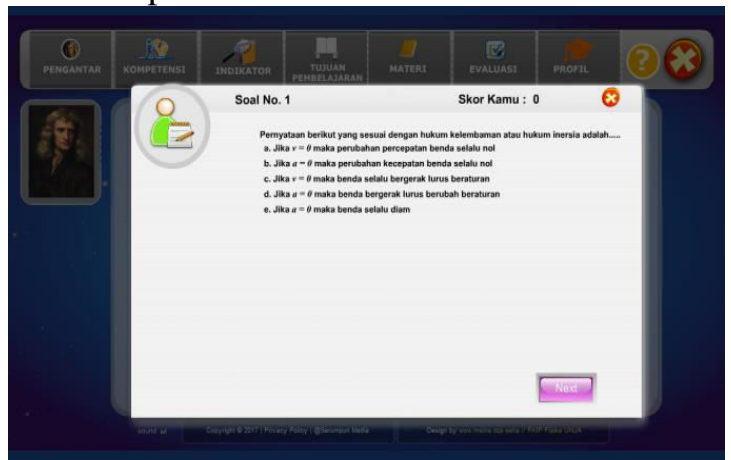


9. Tampilan profil

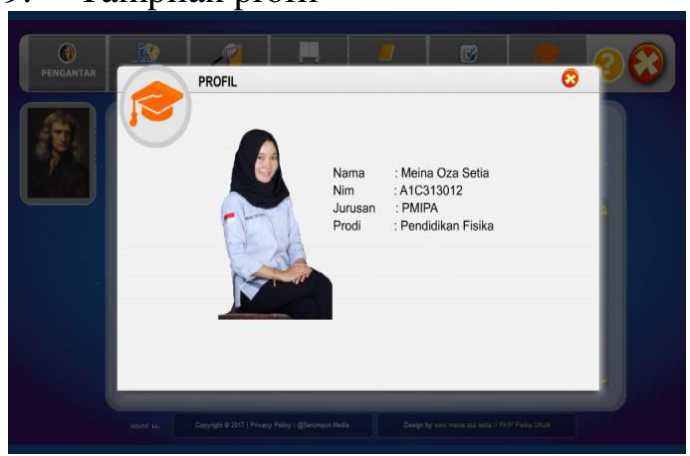

10. Tampilan bantuan

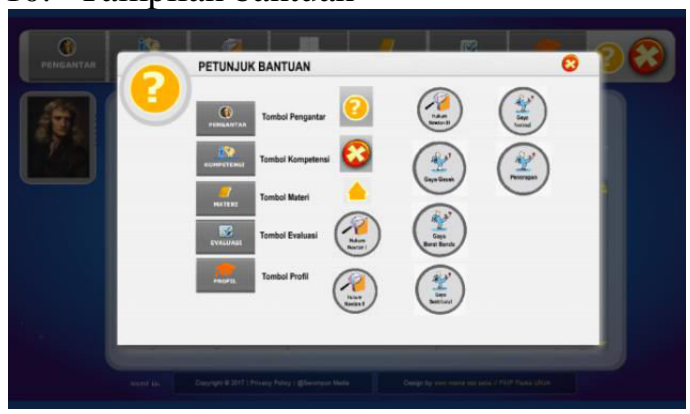

11. Tampilan penutup

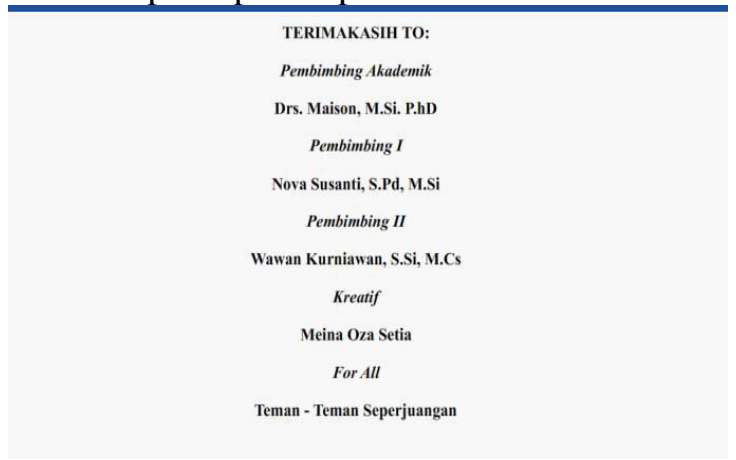

\section{Keunggulan}

Keunggulan yang terdapat pada media pembelajaran yaitu:

1. Bahasa yang digunakan mudah dimengerti.

2. Animasi yang ditampilkan langsung ke layar.
3. Terdapat soal interaktif pada menu evaluasi sehingga siswa dapat melihat skor yang diperoleh dari tes akhir yang dikerjakan secara langsung.

\section{Kelemahan}

Kelemahan yang terdapat pada media pembelajaran yaitu:

1. Belum terdapat simulasi dan video pada media pembelajaran.

2. Hanya bisa digunakan pada komputer atau laptop yang mempunyai aplikasi adobe flash CS 6.

\section{Simpulan dan Saran}

Simpulan

Saran-saran dari tim ahli dan responden (siswa) dapat dijadikan acuan dalam merevisi media pembelajaran dengan menggunakan adobe flash CS 6, media pembelajaran Fisika berisi teks, gambar, musik, tombol dan animasi bergerak.

Media pembelajaran dengan menggunakan adobe flash CS 6 divalidasi oleh tim ahli materi dan tim ahli media pembelajaran. Dari hasil penilaian validasi dari tim ahli materi dan ahli media tersebut terdapat beberapa yang harus direvisi diantaranya pada indikator pembelajaran, tujuan pembelajaran dan musik pengiring, hal tersebut sudah di revisi. Dari kedua penilaian validasi tim ahli materi dan ahli media setelah direvisi dapat disimpulkan bahwa media pembelajaran dengan menggunakan adobe flash CS 6 dinyatakan "layak" untuk diujicoba.

Produk yang telah melalui proses revisi dan validasi, kemudian diujicobakan kepada siswa dengan 28 responden. Dari hasil uji coba, maka didapat hasil persentase tanggapan sebesar $80,1 \%$ yang artinya media pembelajaran Fisika ini layak digunakan sebagai media pembelajaran Fisika pada materi Hukum Newton Tentang Gerak dan Penerapannya untuk SMA kelas X SMA.

Saran

Berdasarkan kesimpulan yang diperoleh di atas serta untuk lebih meningkatkan kemampuan mengembangkan media, maka penulis menyarankan :

1. Media pembelajaran ini dapat dijadikan sebagai media pembelajaran di sekolah.

2. Karena pengembangan ini hanya dilakukan pada materi Hukum Newton tentang Gerak 
dan Penerapannya, maka diharapkan untuk peneliti selanjutnya dapat pula mengembangkan media pembelajaran dengan menggunakan adobe flash CS 6 pada materi lainnya.

3. Mengembangkan media pembelajaran dengan menggunakan adobe flash CS 6 membutuhkan waktu yang cukup lama, jadi guru ataupun peneliti selanjutnya harus merencanakan dan mempersiapkan segala sesuatu jauh-jauh hari.

4. Media pembelajaran Fisika ini sebaiknya digunakan pada sekolah-sekolah yang sudah berbasis ICT.

5.

\section{Daftar Pustaka}

Arsyad, A. 2015. Media Pembelajaran. Jakarta : PT Raja Grafindo Persada.

Arifin, A. 2014. Pengembangan Media Pembelajaran Interaktif Matematika Berbasis Pendidikan Karakter Menggunakan Macromedia Flash Professional 8 Pada Pokok Bahasan Aritmetika Sosial Kelas VII. Yogyakarta :Universitas Islam Negri Sunan KalijagaYogyakarta

Asyhar, R. 2010. Kreatif mengembangkan media pembelajaran. Jakarta: Gaung Persada Press

Direktorat Pembinaan SMA. 2010. Juknis Penyusunan Perangkat Penilaian Afektif di SMA. Jakarta: Kementerian Pendidikan Nasional

Madcoms. 2013. Adobe Flash CS6 Mahir dalam 7 Hari.Yogyakarta: ANDI

Meilisa, M. N.2014. Pengembangan Media Pembelajaran Interaktif Berbasis Adobe Flash CS6 Pada Materi Himpunan Untuk Siswa Kelas VII SMP/MTs.Malang: Universitas Muhammadiyah Malang.

Mulyatiningsih. 2014. Metode Penelitian Terapan Bidang Pendidikan. Bandung : ALFABETA

Perdiansyah, F, Dkk.2014. Pengembangan Media Pembelajaran Fisika Dengan Program Adobe Flash CS 6 Berbasis
Ketrampilan Proses Sains.Jakarta: Universitas Negeri Jakarta.

Pribadi, B.A. 2014. Desain dan Pengembangan Program Pelatihan Berbasis Kompetensi: Implementasi Model ADDIE. Jakarta: KENCANA

Sadiman, A. S .2009. Media Pendidikan (pengertian, pengembangan dan pemanfaatannya).Jakarta: Rajawali Pers.

Saputro, A. B.2014. Pengembangan Media Pembelajaran Matematika Dengan Menggunakan Adobe Flash Professional CS6 Pada Materi Peluang Kelas XI SMA 10 Tanjung Jabung Timur.Jambi : Universitas Jambi.

Subagya, H.2013. Konsep dan Penerapan Fisika SMA/MA kelas X. Jakarta : PT Bumi Aksara

Sugiyono. 2014. Metode Penelitian Pendidikan :Pendekatan Kuantitatif Kualitatif, dan $(R \& D)$. Bandung : Alpabetha

Sunarti. 2014. Penilaian Dalam Kurikulum 2013. Yogyakarta : ANDI

Wakhid, A. N.2014. Pengembangan Media Pembelajaran Dengan Adobe Flash CS6 Untuk Menyajikan Soal dan Pembahasan Ujian Nasional Fisika SMA Berbasis Multirepresentasi.Yogyakarta:Univer sitas Islam Negeri Sunan Kalijaga.

Walgito, B.2010. Pengantar Psikologi Umum. Yogyakarta: Andi Pffset.

Widoyoko, S. E. P. 2016. Teknik Penyusunan Instrumen Penelitian. Yogyakarta: Pustaka Belajar 